\title{
The Progressivity of the First Income Tax in the United Kingdom: Data from 1799/1800 and 1815/1816
}

\author{
Alexander M. G. Gelardi \\ University of St. Thomas \\ Minneapolis MN USA
}

\begin{abstract}
William Pitt the Younger's government introduced a national income tax in the United Kingdom in 1799 to help pay for the war against France. When the war ended, income tax was repealed. The tax was unpopular from the beginning and was regarded as being unfair. Progressivity is generally regarded as being a measure of equity. This research looks at the progressivity at the beginning and end of the first UK income tax. Both the Suits and Kakwani indices are used to measure the level of progressivity. It was found that at the beginning the tax was very progressive for taxpayers. However, by the time it was repealed it, the level of progressivity was much reduced.
\end{abstract}

Keywords: Income Tax; Progressivity; United Kingdom; Suits Index; Kakwani Index; William Pitt

\section{INTRODUCTION}

Equity is one of the main canons of an ideal tax system (Smith 1963[1776]). One of the elements of equity, vertical equity, is often regarded to be progressivity. Progressivity is a method of taxation in which the rate of tax increases as the base (income) increases but more rapidly (Shehab, 1953). However, the origin of the principle is much older and probably lost in antiquity. Both the Greeks and the Romans adhered to the principle (Plutarch circa 100:1992, Gibbon, 1776:1909 p.204). The violation of the principle has had some dramatic effects. For example, the English Peasants' Revolt (including the beheading of the Chancellor by the rioters) in 1381 had, as one of its main triggering events, the abandonment of the progressivity of the poll tax (Corbett, 1901). The tax had been charged at graduated levels from $£ 613 \mathrm{~s} 4 \mathrm{~d}$ for rich nobles to a groat (4d) for a labourer. In 1380, the tax was made a flat three groats for all persons over fifteen years old (Corbett, 1901). In 1990, again in England, a graduated property-type tax was replaced by an almost flat poll-type tax (Smith, 1991). This change resulted in riots in London and widespread civil disobedience (as well as possibly contributing to the downfall of the Prime Minister, Margaret Thatcher) (James and Nobes, 1992, Slemrod and Bakija, 1996).

When Congress, in the United States, debated introducing a federal income strong references were made to the UK income tax system and rationales (Seligman, 1911). The UK system at the time was very much predicated on the original tax system under Pitt (Shehab, 1953). Since progressivity is a mainstay of the US system, understanding progressivity in Pitt's (and immediate successors') income tax would be of considerable interest.

\section{INCOME TAX DURING THE NAPOLEONIC WAR}

In 1799 the British Parliament, under Prime Minister William Pitt (the Younger), passed what is often considered to be the first major national Income Tax (39 George III c.13). This tax was essentially a war tax and, indeed, was often referred to as the War Income Tax. In fact, it has 
been called "the tax that defeated Napoleon" (Sabine, 1966). However, the income tax was generally regarded as being odious and unfair and was extremely unpopular. The tax was repealed in 1803 with the Treaty of Amiens, but since hostilities resumed in the same year, it was reinstated by Henry Addington's government. On the reintroduction of the income tax there were some major technical amendments. Further technical amendments were made in 1805 and 1806, but in each case, the tax retained its overall structure. The 1806 Act ( 43 Geo III c. 65) stated that the Property Tax (as Income Tax was known since 1803) would continue "during the present war until the Sixth Day of April next after the Ratification of a Definitive Treaty of Peace". The Napoleonic War ended with the battle of Waterloo and the Second Treaty of Paris in 1815. The government was keen to continue with the tax. The people were not so keen for it to continue. Many petitions for its repeal were presented to parliament in 1815 and 1816 (Hansard, 1816a: Tayler, 1853).

As a result of the petitions, the government acquiesced to go to Parliament, hoping that it would vote in favor of the continuance of income tax. In May 1816, on behalf of Lord Liverpool's government, the Chancellor of the Exchequer, Nicholas Vansittart, introduced a motion to let the income tax (the Property Tax) continue. Vansittart spoke eloquently, but denied that the government had pledged to end the tax with the end of the war. However, it was pointed out that the 1806 Act had the above quoted wording (to "Shouts of Hear, hear, hear") (Hansard, 1816a, col.450). The motion was defeated. The votes were 201 for the continuance and 238 against. Thus, the motion was defeated by only thirty-seven votes. Hansard reported "a loud cheering took place which lasted several minutes. Similar exultation was manifested by the crowd of strangers in the lobby and the avenues of the House" (Hansard, 1816a, col. 451). The government ordered all records regarding the income tax be destroyed (Hansard, 1816b: Seligman, 1911). If this had happened efficiently, then this research would have been impossible. Luckily some documents have survived and data for the years 1799 (ending April 1800) and 1815 (ending April 1816) will be used in this research.

\section{9/1800 Tax Rates}

Fairness, or equity, was regarded as a major reason for the introduction of a tax on income. An anonymous contemporary commentator stated "the intention of the Legislature [is] to establish an equity of Taxation, as far as it is practicable by human means ... namely, the ascertainment, by just and fair rules, of each person's Income, in order to [sic] a proportionate Assessment." (Anon., p 1)

The concept of fairness acknowledges that persons who are in dis $\urcorner$ similar economic situations should be taxed differently (Smith 1963[1776]). Though, as can be seen, Adam Smith wrote this before the income tax system was used in Britain. Often, this view of fairness is interpreted as meaning that taxpayers who have higher incomes should bear a relatively greater proportion of the tax burden. This is known as progressivity. Overall, in a progressive system, the richer taxpayers pay a disproportionately greater amount of the overall tax. Pitt's 1799 income tax is generally considered to have a $10 \%$ rate. This is true but only for incomes over $£ 200$. Below that income level the tax system was designed with a certain amount of progressivity. All income below $£ 60$ was exempt. Income between $£ 60$ and $£ 200$ was taxed at different rates rising from $1 / 120$ th to $1 / 11$ th, and incomes over $£ 200$ were taxed at a flat $1 / 10$ th. There were very few deductions, mainly for children and based on the age of the child and the income of the taxpayer. Even this child deduction was progressive in that taxpayers' with lower incomes received a higher rate of income. For example for taxpayers with income between $£ 60$ and $£ 400$ the deduction was 5\%; with incomes $£ 400$ to $£ 1,000$ the deduction was 
$4 \%$ for children six and over and 3\% for younger children and so on. Table 1 shows the tax rates for $1799 / 1800$.

Table1: Tax Rates for Tax Year 1799/1800

\begin{tabular}{|c|c|c|c|c|c|c|c|c|c|}
\hline \multicolumn{3}{|c|}{ Income range } & \multirow[t]{2}{*}{$\underline{\text { Rate }}$} & \multirow[t]{2}{*}{ Rate \% } & \multicolumn{3}{|c|}{ Income range } & \multirow[t]{2}{*}{ Rate } & \multirow[t]{2}{*}{$\underline{\text { Rate } \%}$} \\
\hline$£$ & & $£$ & & & $£$ & & $£$ & & \\
\hline$<60$ & & & & $0.0000 \%$ & 130 & to & $<135$ & $1 / 28$ & $3.5714 \%$ \\
\hline 60 & to & $<65$ & $1 / 120$ & $0.8333 \%$ & 135 & to & $<140$ & $1 / 26$ & $62 \%$ \\
\hline 65 & to & $<70$ & $1 / 95$ & $1.0526 \%$ & 140 & to & $<145$ & $1 / 24$ & $67 \%$ \\
\hline 70 & to & $<75$ & $1 / 70$ & $1.4286 \%$ & 145 & to & $<150$ & $1 / 22$ & $4.5455 \%$ \\
\hline 75 & to & $<80$ & $1 / 65$ & 1.53 & 150 & to & $<155$ & $1 / 20$ & $0 \%$ \\
\hline 80 & to & $<85$ & $1 / 60$ & $1.6667 \%$ & 155 & to & $<160$ & $1 / 19$ & $32 \%$ \\
\hline 85 & to & $<90$ & $1 / 55$ & 1.81 & 160 & to & $<165$ & $1 / 18$ & $56 \%$ \\
\hline 90 & to & $<95$ & $1 / 50$ & & 65 & to & $<170$ & $1 / 17$ & $4 \%$ \\
\hline 95 & to & $<100$ & $1 / 45$ & $2.2222 \%$ & 170 & to & $<175$ & $1 / 16$ & $0 \%$ \\
\hline 100 & to & $<105$ & $1 / 40$ & $2.5000 \%$ & 175 & to & $<180$ & $1 / 15$ & $6.6667 \%$ \\
\hline 105 & to & $<110$ & $1 / 38$ & $2.6316 \%$ & 180 & to & $<185$ & $1 / 14$ & $7.1429 \%$ \\
\hline 110 & to & $<115$ & $1 / 36$ & $2.7778 \%$ & 185 & to & $<190$ & $1 / 13$ & $7.6923 \%$ \\
\hline 115 & to & $<120$ & $1 / 34$ & $2.9412 \%$ & 190 & to & $<195$ & $1 / 12$ & $8.3333 \%$ \\
\hline 120 & to & $<125$ & $1 / 32$ & $3.1250 \%$ & 195 & to & $<200$ & $1 / 11$ & $9.0909 \%$ \\
\hline 125 & to & $<130$ & $1 / 30$ & $3.3333 \%$ & $\geq 200$ & & & $1 / 10$ & $10.0000 \%$ \\
\hline
\end{tabular}

\section{5/16 Tax Rates}

In 1806, there was another major change in the rates of income tax. By that time (in fact, from 1803) the tax was called the Property Tax. This was done mainly to hide the fact that it was a tax on income, as the 1799 Income tax was hated and often evaded. Table 2 shows how much tax there was to be charged on each pound of income between $£ 50$ and $£ 150$, as set out in the legislation 


\section{Table 2: Tax Amounts for Tax Year 1815-1816}

\begin{tabular}{|c|c|c|c|c|c|c|c|}
\hline Income & Tax. & Income & Tax. & Income & Tax & Income & Tax \\
\hline$f$ & f s. d. & $f$ & f s. d. & $f$ & f s. d. & $f$ & $f \quad$ s. $\quad d$ \\
\hline$\leq 50$ & Exempt & 75 & 3.15 .0 & 100 & 7 10. 0 & 125 & 115.0 \\
\hline 51 & 0. 3. 0. & 76 & 3.18 .0 & 101 & 7 13. 0 & 126 & 118.0 \\
\hline 52 & 0.6 .0$. & 77 & $\begin{array}{lll}4 & 1 . & 0\end{array}$ & 102 & $7 \quad 16.0$ & 127 & 11. 11. 0 \\
\hline 53 & 0. 9. 0. & 78 & $\begin{array}{lll}4 & 4 . & 0\end{array}$ & 103 & 7 19. 0 & 128 & 11. 14. 0 \\
\hline 54 & 0.12. 0 . & 79 & $\begin{array}{lll}4 & 7 . & 0\end{array}$ & 104 & 82.0 & 129 & 11. 17. 0 \\
\hline 55 & 0.15 .0$. & 80 & 4.10. 0 & 105 & 85.0 & 130 & 12. 0.0 \\
\hline 56 & 0.18 .0$. & 81 & 4.13 .0 & 106 & $\begin{array}{lll}8 & 8 . & 0\end{array}$ & 131 & 123.0 \\
\hline 57 & 1. 1.0 . & 82 & 4.16 .0 & 107 & \& 11. 0 & 132 & 12. 6.0 \\
\hline 58 & 1. 4.0 & 83 & $\begin{array}{lll}4.19 & 0\end{array}$ & 108 & 814.0 & 133 & 129.0 \\
\hline 59 & 1. 7.0 & 84 & 52.0 & 109 & 817.0 & 134 & 1212.0 \\
\hline 60 & 1. 10.0 & 85 & 5 5. 0 & 110 & $\begin{array}{lll}9 & 0 . & 0\end{array}$ & 135 & 1215.0 \\
\hline 61 & 1. 13.0 & 86 & 58.0 & 111 & 93.0 & 136 & 1218.0 \\
\hline 62 & 1. 16.0 & 87 & 511.0 & 112 & 96.0 & 137 & 131.0 \\
\hline 63 & 1. 19.0 & 88 & 514.0 & 113 & 9 9. 0 & 138 & 13 4. 0 \\
\hline 64 & 2. 2. 0 & 89 & 5.17. 0 & 114 & 9 12. 0 & 139 & 13. 7. 0 \\
\hline 65 & 2. 5.0 & 90 & $\begin{array}{lll}6 & 0.0 & 0\end{array}$ & 115 & 9 15. 0 & 140 & 13. 10. 0 \\
\hline 66 & 2. 8.0 & 91 & 6 3. 0 & 116 & 918.0 & 141 & 13. 13.0 \\
\hline 67 & 2. 11.0 & 92 & $\begin{array}{lll}6 & 6.0\end{array}$ & 117 & 101.0 & 142 & 13. 16. 0 \\
\hline 68 & 2. 14.0 & 93 & $\begin{array}{lll}6 & 9.0\end{array}$ & 118 & 10 4. 0 & 143 & 14. 19. 0 \\
\hline 69 & 2. 17.0 & 94 & 612.0 & 119 & 107.0 & 144 & 14. 2. 0 \\
\hline 70 & 30.0 & 95 & 615.0 & 120 & 1010.0 & 145 & 14. 5. 0 \\
\hline 71 & 33.0 & 96 & 6.18 .0 & 121 & 1013.0 & 146 & 14. 8.0 \\
\hline 72 & 36.0 & 97 & $\begin{array}{lll}7 & 1 . & 0\end{array}$ & 122 & 1016.0 & 147 & 14. 11. 0 \\
\hline 73 & 39.0 & 98 & 7 4. 0 & 123 & 1012.0 & 148 & 14. 14. 0 \\
\hline \multirow[t]{2}{*}{74} & 312.0 & 99 & 7 7. 0 & 124 & 112.0 & 149 & 14. 17. 0 \\
\hline & & & & & & $\geq 150$ & 15. 0.0 \\
\hline
\end{tabular}

Table 2 show the tax rates in terms of tax payable. To put these rate in terms that can be compared to the $1799 / 1800$ tax rates, table 3 converts the tax payable to percentages. 
Table 3: Tax Rates for Tax Year 1815-1816

\begin{tabular}{cccccccc}
\multicolumn{2}{l}{ Income Rate $\%$} & Income Rate $\%$ & Income & Rate $\%$ & Income & Rate $\%$ \\
\hline$£$ & & $f$ & & $f$ & & $f$ & \\
$\leq 50$ & $0.00 \%$ & 75 & $5.00 \%$ & 100 & $7.50 \%$ & 125 & $9.00 \%$ \\
51 & $0.29 \%$ & 76 & $5.13 \%$ & 101 & $7.57 \%$ & 126 & $9.05 \%$ \\
52 & $0.58 \%$ & 77 & $5.26 \%$ & 102 & $7.65 \%$ & 127 & $9.09 \%$ \\
53 & $0.85 \%$ & 78 & $5.38 \%$ & 103 & $7.72 \%$ & 128 & $9.14 \%$ \\
54 & $1.11 \%$ & 79 & $5.51 \%$ & 104 & $7.79 \%$ & 129 & $9.19 \%$ \\
55 & $1.36 \%$ & 80 & $5.63 \%$ & 105 & $7.86 \%$ & 130 & $9.23 \%$ \\
56 & $1.61 \%$ & 81 & $5.74 \%$ & 106 & $7.92 \%$ & 131 & $9.27 \%$ \\
57 & $1.84 \%$ & 82 & $5.85 \%$ & 107 & $7.99 \%$ & 132 & $9.32 \%$ \\
58 & $2.07 \%$ & 83 & $5.96 \%$ & 108 & $8.06 \%$ & 133 & $9.36 \%$ \\
59 & $2.29 \%$ & 84 & $6.07 \%$ & 109 & $8.12 \%$ & 134 & $9.40 \%$ \\
60 & $2.50 \%$ & 85 & $6.18 \%$ & 110 & $8.18 \%$ & 135 & $9.44 \%$ \\
61 & $2.70 \%$ & 86 & $6.28 \%$ & 111 & $8.24 \%$ & 136 & $9.49 \%$ \\
62 & $2.90 \%$ & 87 & $6.38 \%$ & 112 & $8.30 \%$ & 137 & $9.53 \%$ \\
63 & $3.10 \%$ & 88 & $6.48 \%$ & 113 & $8.36 \%$ & 138 & $9.57 \%$ \\
64 & $3.28 \%$ & 89 & $6.57 \%$ & 114 & $8.42 \%$ & 139 & $9.60 \%$ \\
65 & $3.46 \%$ & 90 & $6.67 \%$ & 115 & $8.48 \%$ & 140 & $9.64 \%$ \\
66 & $3.64 \%$ & 91 & $6.76 \%$ & 116 & $8.53 \%$ & 141 & $9.68 \%$ \\
67 & $3.81 \%$ & 92 & $6.85 \%$ & 117 & $8.59 \%$ & 142 & $9.72 \%$ \\
68 & $3.97 \%$ & 93 & $6.94 \%$ & 118 & $8.64 \%$ & 143 & $9.76 \%$ \\
69 & $4.13 \%$ & 94 & $7.02 \%$ & 119 & $8.70 \%$ & 144 & $9.79 \%$ \\
70 & $4.29 \%$ & 95 & $7.11 \%$ & 120 & $8.75 \%$ & 145 & $9.83 \%$ \\
71 & $4.44 \%$ & 96 & $7.19 \%$ & 121 & $8.80 \%$ & 146 & $9.86 \%$ \\
72 & $4.58 \%$ & 97 & $7.27 \%$ & 122 & $8.85 \%$ & 147 & $9.90 \%$ \\
73 & $4.73 \%$ & 98 & $7.35 \%$ & 123 & $8.90 \%$ & 148 & $9.93 \%$ \\
74 & $4.86 \%$ & 99 & $7.42 \%$ & 124 & $8.95 \%$ & 149 & $9.97 \%$ \\
& & & & & & $\geq 150$ & $10.00 \%$
\end{tabular}

\section{RESEARCH METHODOLOGY}

In this research I use two indices, the Suits index and the Kakwani index to measure progressivity. The Suits index is based on the Gini Coefficient. If the cumulative tax burden is graphed against the cumulative income, this is the income concentration curve. A tax that is totally proportional (such as a flat tax) would have an income concentration that is along the diagonal $\left(45^{\circ}\right.$ line). A progressive tax will have the income concentration (Lorenz curve) below the diagonal and a regressive tax would have the income concentration above the diagonal (Suits, 1977). The Suits index is constructed by depicting the area under the diagonal as $\mathrm{K}$ and area below the income concentration curve as $\mathrm{L}$. The Suits index is $\mathrm{S}=1-\mathrm{L} / \mathrm{K}$. The Suits index goes from -1.0 to +1.0 . A proportional tax would have a Suits index of zero. A Suits index of above +0.2 is regarded as being very progressive. The Suits index has often been used in tax research by accounting faculty (Dunbar and Nordhauser, 1991; Luttman and Spindle, 1994; Ricketts, 1990)

The Kakwani index has been used much by economists and others (Kakwani, 1977, 1987; Loizides, 1988; Seethara $\operatorname{man}, 1994$; Seetharaman and Iyer, 1995). The Kakwani index is similar to the Suits index, however the Kakwani index uses two concentration curves; the cumulative percentage of tax liability and the cumulative percentage of income, against the cumulative population in each tax band. In other words, the x-axis is the cumulative percentage of taxpayers and the $y$-axis is the cumulative percentage of tax liability and the cumulative percentage of income. The Kakwani index can be defined as the difference between 
concentration index of the tax $(1 / 2$ - the area under the tax curve) $/ 1 / 2)$ and the concentration of the income $(1 / 2$ - the area under the income curve $) / 1 / 2)$.

It can be more formally depicted as:

$$
K=2 \int_{0}^{1} T(P) d P-2 \int_{0}^{1} Y(P) d P
$$

Where $\mathrm{P}=$ cumulative percentage of taxpayer

$\mathrm{T}(\mathrm{P})=$ Lorenz curve of Tax payment: thus, the first term is twice the area under the Tax curve.

$Y(P)=$ Lorenz curve of Pre-tax Income curve: thus, the second term is twice the area under the pre-tax income curve.

A purely proportional tax would make the tax curve lie exactly over the income curve and the index would be zero. A progressive tax system would be positive, whereas a regressive tax sys $\neg$ tem would be negative.

The two indices differ in emphasis. The Suits index is concerned with the income of the taxpayers, whereas the Kakwani index is concerned with the number of taxpayers (Seetharaman and Iyer, 1995). By looking at both, a better view can be had of the progressivity of the early income tax system.

Data was obtained from such sources as: Digest of all the Accounts relating to Population, Productions, and Revenues, Financial Operations Etc. Edited by J. Marshall and Hand-book of Income Tax Law and Practice by Charles Senior. A Short History of English Agriculture by W.H.R. Curtler.

\section{9/1800 Tax Year}

\section{RESULTS}

Suits Index the two indices give consistent results. The Suites Index for the 1799/1800 tax year is 0.20 which is regarded as being very progressive.

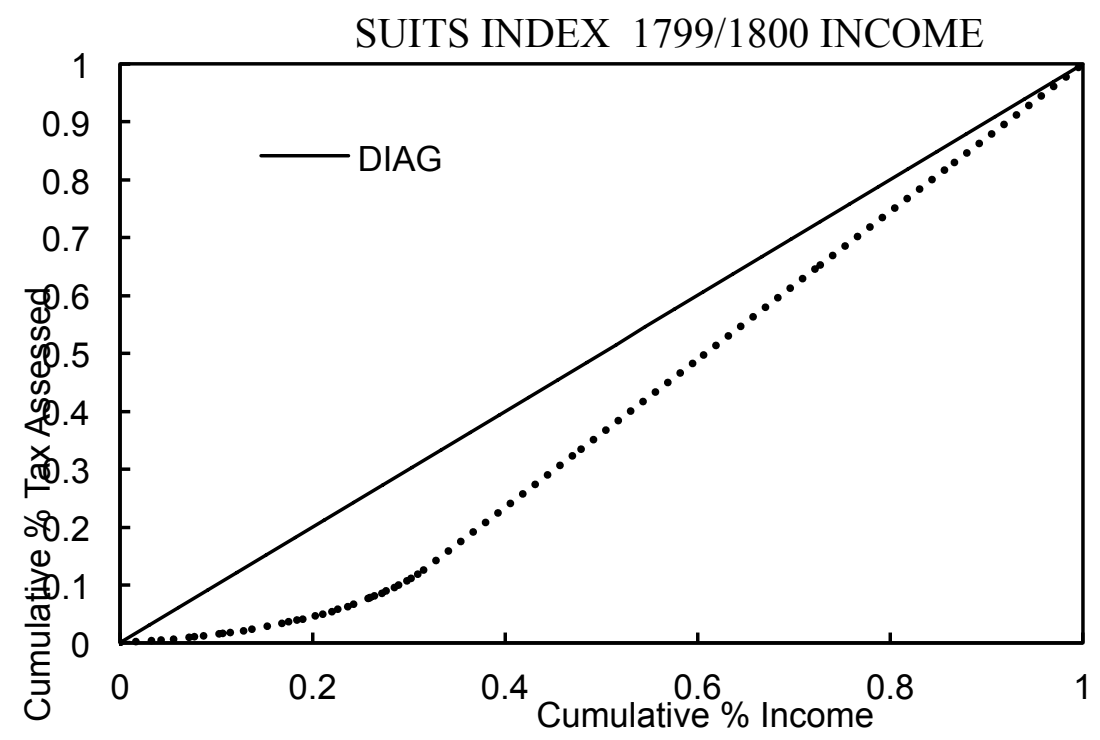

Figure 1: Suits Index for 1799/1800 Income

As can be seen be seen from the graph the area under the diagonal shows that the tax assessed on persons with little income (but over $£ 60$ ) is less than on those with higher income. 


\section{Kakwani Index}

The Kakwani index is 0.21 . This supports the conclusion of the Suits index.

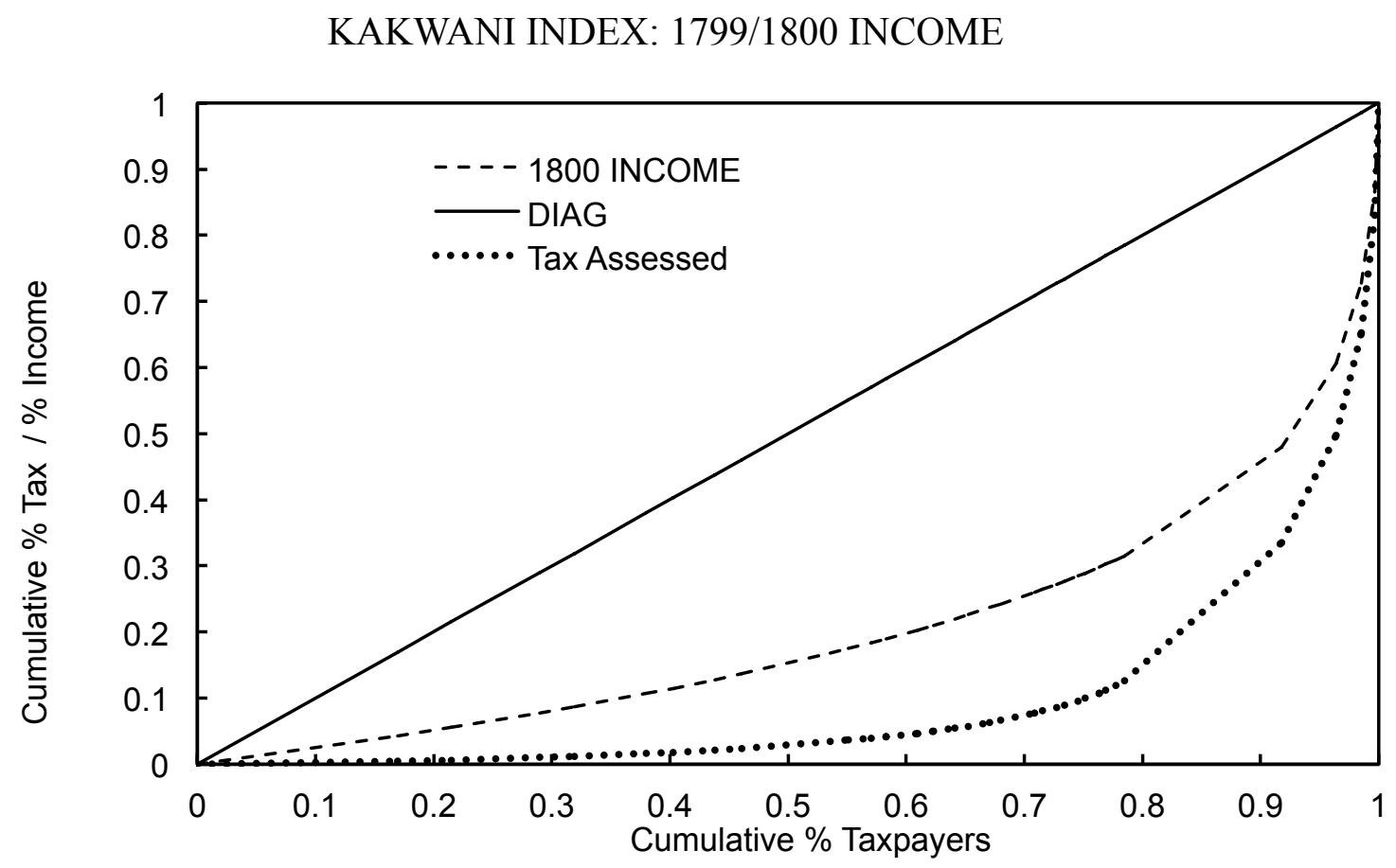

Figure 2: Kakwani Index for 1799/1800 Income

This graph compares the income and tax assessed with respect to the number of taxpayers in each tax group. The graph shows that the area between the income and the tax assessed curves is large. Thus, the income tax system, when introduced, was very progressive.

\section{5/1816 Tax Year}

\section{Suits Index}

The progressivity of the 1815/1816 tax year is much lower than that of the $1799 / 1800$ tax year. The Suites Index is 0.09 , which indicates a low level of progressivity. This is seen in the figure 3 below. 


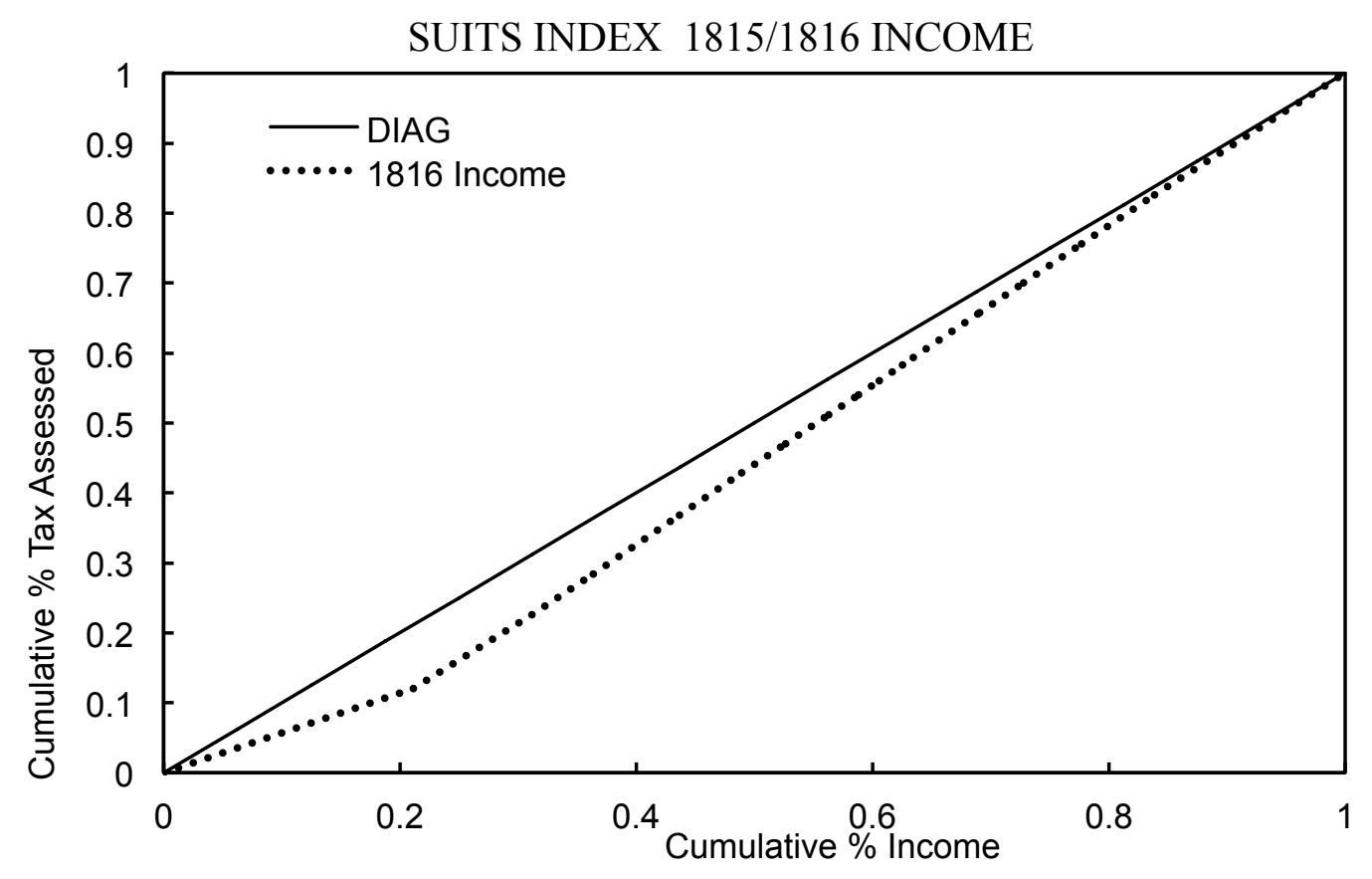

Figure 3: Suits Index for 1815/1816 Income

The graph in figure 3 shows that the area between the income line and the diagonal is fairly small. This indicates that there was little progressivity in the tax system in 1815/1816.

\section{Kakwani Index}

The Kakwani Index is 0.12 and thus, again, similar to the Suits Index. Again, the graph below shows the relative areas between the lines.

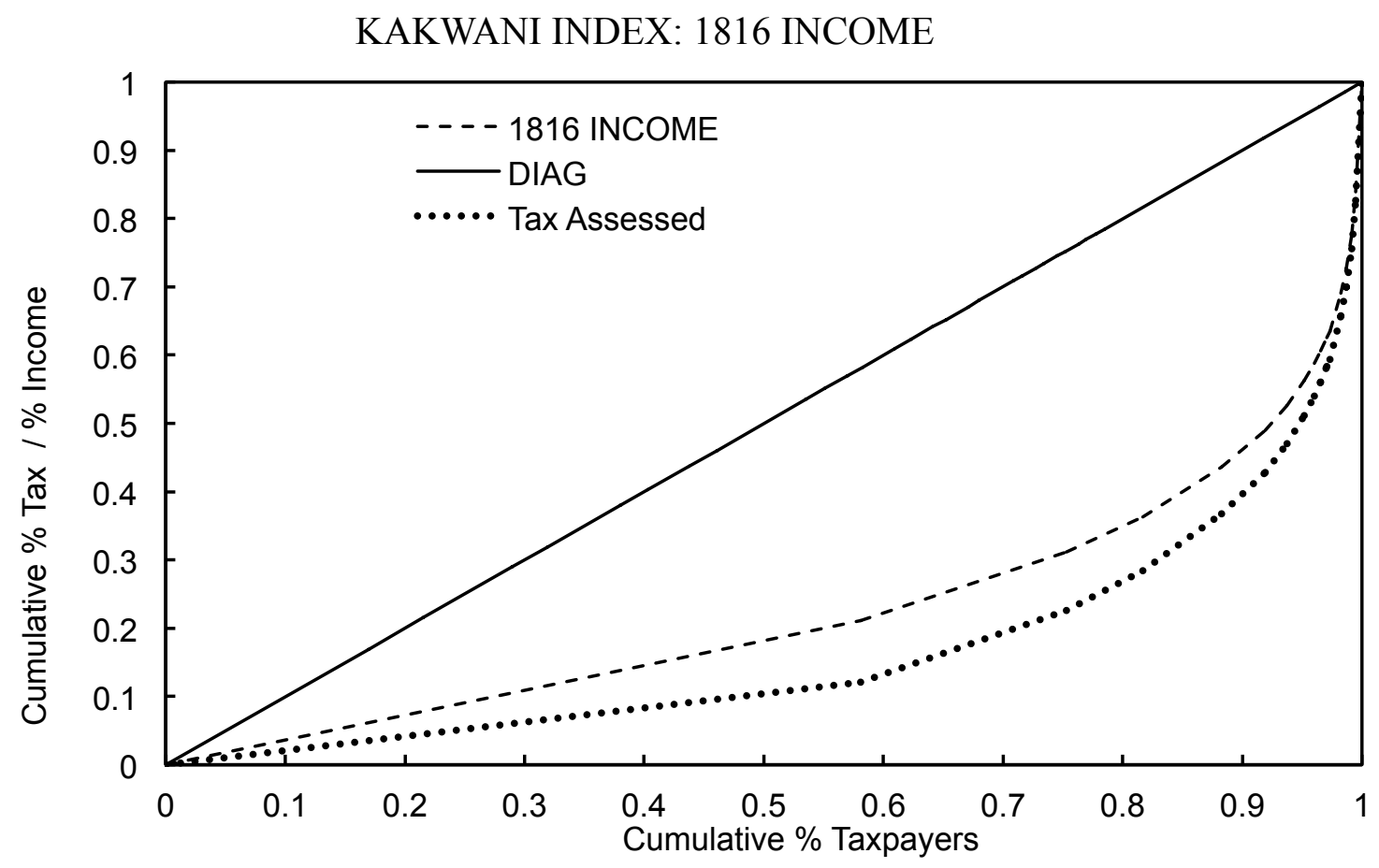

Figure 4 Kakwani Index for 1815/1816 income. 
The graph in Figure 4 shows that area between the income line and the tax assessed curve is relatively small. This indicates that by the time the first income tax was repealed, the system as not very progressive for taxpayers. Thus, the Income tax system during the Napoleonic War became started as being very progressive, but by the time it was repealed at the end of the war, progressivity was much reduced.

\section{CONCLUSION AND FUTURE RESEARCH}

William Pitt's income tax lasted from 1799 to 1816 to help pay for the Napoleonic war. The tax lasted until the end of the war and was repealed in 1816 as a result of popular demand; even though the government wished to continue the tax. Although the tax was considered to be unfair, the rate schedules did have some progressivity built-in, as shown in the results.

The results show that the $1799 / 1800$ rates were fairly progressive for taxpayers in the system. By the time that the income tax was repealed, the scale of progressivity had been reduced. The 1815/16 income tax rates were still progressive but somewhat less so than when the War Income Tax was introduced.

A limitation of this research is that the information on income and number of persons with income is limited to those assessed to tax. That is, only persons with income over $£ 60$ in 1799 and over $£ 50$ in 1815 were used in the analysis. An extension of this research would be to estimate the number of persons with income less than those amounts and the unassessed income. This would require obtaining information on working persons and their wages. The results of such an extension to this research would be most interesting.

\section{References}

Anonymous, 1799. Observations, etc. upon the Act for Taxing Income in Which the Principles and Provisions of the Act are fully Considered etc. etc." London: Bunney and Gold.

Brunt L. and Meidell, E. (n.d.) "How fast and how broad was British industrialization? Evidence from a synthetic occupational census for 1801" Working Paper NHH Bergen.

Clark, G. (n.d.). Farm Wages and Living Standards in the Industrial Revolution: England, 1670-1850. Working Paper Series. University of California-Davies. Department of Economics.

Commissioners of Inland Revenue, 1857. First Report of the Commissioners of Inland Revenue on Inland Revenue, London: Her Majesty's Stationary Office.

Corbett, W.J. 1901. "The Agricultural Revolution” in Social England, vol II.I, Eds. Trail, H.D. and J.S. Mann, Cassel and Co Ltd.

Curtler, W.H.R. 1909. A Short History of English Agriculture. Oxford: Clarendon Press

Dunbar, A. and S. Nordhauser. 1991. “Is the child Care Credit Progressive?” National Tax Journal 44 pp. $519-528$.

Field, J. F. 2013 “Domestic Wages: Domestic service, gender, and wages in rural England, c.1700-1860.” The Economic History Review 66, 1, pp. 249-272.

Gibbon, E. 1776:1909. the Decline and fall of the Roman Empire. Reprinted, ed. J.B. Bury, London: Methuen and Co.

Hansard. T.C. 1816a. The Parliamentary Debates from the year 1803 to the Present Time. HC deb. 18 March 1816, Vol 33. Cols. 421-451.

Hansard. T.C. 1816b. The Parliamentary Debates from the year 1803 to the Present Time. HC deb. 30 May 1816 , Vol 34. Cols. 928-929.

James, S. and C. Nobes. 1992. The Economics of Taxation, 4h ed. London: Prentice Hall International (UK) Ltd. Kakwani, N.C., 1977. “Measurement of Tax Progressivity: An International Comparison.” Economic Journal 87 (March) pp. 71-80. 
Kakwani, N.C. 1987. "Measures of Tax Progressivity and Redistribution Effects: A Comment." Public Finance. 42, 3: 431-434.

Marshall, J. 1833. Digest of all the Accounts relating to Population, Productions, Revenues, and Financial Operations Etc. Ed. J. Marshall, London: J Haddon.

Loizides, I. 1988. The Decomposition of Progressivity Indices with Applications to the Greek Taxation System. Public Finance. 43, 2: 236-247.

Luttman, S. and R. Spindle. 1994. "An Evaluation of the Revenue and Equity Effects of Converting Exemptions and Itemized Deductions to a Single Non-refundable Tax Credit." Journal of the American Taxation Association. 16, pp. 43-62.

Plutarch. C.100:1992. Lives of the Noble Grecians and Romans. Reprinted in Great Books series, Encyclopædia Britannica.

Ricketts, R. C. 1990. "Social Security Growth versus Income Tax Reform: An Analysis of Progressivity and Horizontal Equity in the Federal Tax System." Journal of the American Taxation Association. 11, pp. 34-50.

Sabine, B.E.V. 1966. A History of Income Tax. London: George Allen \& Unwin Ltd.

Seetharaman, A. 1994. An Isolation of the Effects of Personal Deductions, Tax Credits, and the Tax Rate Schedule on U.S. Individual Income Tax Progressivity and Income Inequity. The Journal of the American Taxation Association. 16 (spring): 101-121.

Seetharaman, A. and G.S. Iyer. 1995. "A Comparison of Alternative Measures of Tax Progressivity: The Case of the Child and Dependent Care Credit”. The Journal of the American Taxation Association. 17 (spring): 42-70.

Seligman, E.R.A. 1911. The Income Tax: A Study of the History, Theory, and Practice of Income Tax at Home and Abroad. New York: The Macmillan Company.

Senior, C. 1863. Hand-book of Income Tax Law and Practice. London: Simpkin, Marshall \& Co.

Shehab, F. 1953. Progressive Taxation. Oxford: The Clarendon Press.

Smith, A. 1776:1963: An Inquiry into the Nature and Causes of the Wealth of Nations. Reprinted. Chicago: Irwin.

Smith, P. 1991. "Lessons from the British Poll Tax Disaster". National Tax Journal. 44 (December): pp. 421-436.

Slemrod, J. and J. Bakija. 1996. Taxing Ourselves: A Citizen's Guide to the Great Debate Over Tax Reform. Cambridge, MA: The MIT Press.

Suits, D. 1977. “The Measurement of Tax Progressivity.” The American Economic Review 67(4) pp. 747-752

Tayler, W. 1853. The History of the Taxation of England. London: Hope \& Co. 